\title{
KOMERCJALIZACJA JAKO ELEMENT MODELU PROCESOWEGO
}

\author{
INNOWACJI
}

Andrzej H. Jasiński

Uniwersytet Warszawski

\begin{abstract}
Abstrakt
Celem niniejszego artykułu jest pokazanie koncepcji komercjalizacji jako jednego z elementów modelu procesowego innowacji technicznej. Po omówieniu problemu komercjalizacji wyniku badań naukowych Autor przechodzi do przedstawienia kwestii komercjalizacji nowego produktu. Uzasadnia także konieczność umiejętnego wsparcia marketingowego dla osiagnięcia sukcesu komercjalizacji.
\end{abstract}

\section{Wprowadzenie}

Komercjalizacja (dosłownie: doprowadzenie do sprzedaży) to proces niezwykle istotny pod względem ekonomicznym. Nie sztuką jest bowiem coś wyprodukować - sztuką jest to coś sprzedać. Jak piszą Tidd i Bessant [2011] „Zdolność generowania nowej wiedzy staje się mniej ważna od umiejętności jej sprzedaży (lub kupna) i efektywnego spożytkowania".

Komercjalizacja bywa różnie rozumiana - w odniesieniu do działalności badawczo-rozwojowej i innowacyjnej można ją rozumieć:

1) jako komercjalizację wyniku badań naukowych (projektu badawczego) - przed lub po uzyskaniu dlań ochrony prawnej oraz

2) jako komercjalizacje gotowego wyrobu (usługi), czyli wprowadzenie nowego produktu na rynek.

Oba ujęcia są zasadne i oba powinny być brane pod uwagę.

\section{Komercjalizacja wyniku badań naukowych}

Autorzy przewodnika Komercjalizacja $B+R$ dla praktyków [MNiSW, 2010] ograniczają się wyłącznie do omówienia komercjalizacji wyników prac badawczo-rozwojowych, akcentując zwłaszcza kwestie ochrony prawnej. Komercjalizacja jest przez nich rozumiana jako sprzedaż (w formie bezpośredniej lub pośredniej) wyników prac $\mathrm{B}+\mathrm{R}$, czyli własności intelektualnej, co nie musi prowadzić do wdrożenia. Zdaniem autorów komercjalizacja bezpośrednia - jako forma najprostsza - to 
sprzedaż praw do wyników badań lub udzielenie licencji na korzystanie z tych wyników, natomiast komercjalizacja pośrednia - jako forma najbardziej zaawansowana - to wniesienie wyników badań do spółki istniejącej lub nowej (w postaci aportu).

Jeśli ktoś zgłasza swoje rozwiązanie naukowo-techniczne do ochrony prawnej, widzi jego komercyjny potencjał. Nie oznacza to oczywiście, że komercyjny potencjał wynalazku jest warunkiem zgłoszenia czy uzyskania ochrony prawnej.

Załóżmy, że wynik prac $\mathrm{B}+\mathrm{R}$ przyjął postać nowego rozwiązania naukowo-technicznego, które zostało opatentowane (uzyskało prawo ochronne lub prawo z rejestracji). Jego właściciel ma pięć potencjalnych opcji - może mianowicie [Rosegger, 1996]:

1) postarać się zdobyć niezbędny kapitał i założyć własną firmę, choć może to uczynić jeszcze przed opatentowaniem;

2) sprzedać komuś patent za jednorazową opłatą;

3) udzielić licencji na ten wynalazek za obietnicę okresowych honorariów z tytułu jego komercjalizacji;

4) wnieść go jako wkład (aport) do spółki lub innego przedsiębiorstwa;

5) zdecydować, że na razie ani go nie wykorzysta, ani nie sprzeda; chodzi o jego „zamrożenie”.

Autor rozwiązania naukowo-technicznego ma hipotetycznie takie możliwości również wtedy, gdy nie zdecyduje się na jego ochronę prawną, ale wówczas pozbawia się wielu potencjalnych korzyści. (Pomińmy dalej opcję piątą.)

Ad 1. W krajach wysoko rozwiniętych zalożenie wlasnej firmy to często wykorzystywana opcja, zwłaszcza w przypadku badaczy-autorów nowych rozwiązań naukowo-technicznych, którzy po uzyskaniu patentu (prawa ochronnego lub z rejestracji), albo nawet jeszcze przed, zakładaja własne małe przedsiębiorstwa o dużym ładunku B+R, czyli firmy odpryskowe (spin-off firms).

Ad 2. Przeniesienie prawa własności przemysłowej następuje najczęściej w drodze umowy sprzedaży; rzadziej w grę wchodzi zamiana lub darowizna.

Ad 3. Powszechnie stosowane jest udzielanie licencji, a właściwie jej sprzedaż. Jak wiadomo, licencje można podzielić na dwie grupy: zwykłe oraz szczególne, w tym: licencja otwarta, dorozumiana i przymusowa (zob. Ustawa - Prawo własności przemysłowej, Dz.U. z 2003 r. nr 119, poz. 1117 z późn. zm.), przy czym najczęściej występuje licencja zwykła. Jej przedmiotem może być korzystanie $\mathrm{z}$ rozwiązania chronionego prawami wyłącznymi (patent, prawo ochronne, prawo z rejestracji) - zarówno już 
uzyskanymi, jak i zgłoszonymi do ochrony, a także - co warto zaznaczyć korzystanie $\mathrm{z}$ rozwiązania niezgłoszonego do ochrony prawnej, stanowiącego tajemnicę przedsiębiorcy.

Ad 4. Możliwość wnoszenia dóbr niematerialnych, w tym chronionych prawem własności przemysłowej, jako wkładów do spółek i przedsiębiorstw mieszanych jest przewidziana odrębnymi przepisami oraz w kodeksie handlowym. Wniesienie patentu jako aportu do spółki może zostać sowicie nagrodzone, np. w postaci przydziału akcji lub udziałów.

\section{Komercjalizacja nowego produktu}

W ekonomice i zarządzaniu innowacjami komercjalizacja jest zazwyczaj rozumiana jako wprowadzenie nowego produktu (usługi) na rynek. Jest ona tutaj jednak różnie postrzegana, a mianowicie jako:

1) ostatnia faza procesu innowacyjnego,

2) podetap jednego $z$ etapów procesu innowacyjnego,

3) pierwsza faza cyklu życia produktu,

4) ogniwo łańcucha tworzenia wartości innowacji.

Ad 1. „Klasyczne”, tj. fazowe podejście do procesu innowacyjnego w odniesieniu do innowacji produktowej - przyjmuje, że składa się on z kilku faz, przy czym ostatnią jest wprowadzenie na rynek, czyli właśnie komercjalizacja - zob. np. Jasiński [1998], Krawiec [2000], Pomykalski [2001], Rutkowski [2007], Sosnowska [2000].

Ad 2. Tidd i Bessant [2011] prezentują szersze rozumienie procesu innowacyjnego i rozróżniają cztery jego zasadnicze etapy, w postaci czterech pytań:

1) poszukiwania: „Jak możemy znaleźć okazję do innowacji?”;

2) wybór strategiczny: „Co będziemy robić i dlaczego?”;

3) implementacja ${ }^{1}$ (realizacja pomysłów): „Jak mamy sprawić, że to zadziała?"; to tutaj Autorzy umieszczają badania i rozwój $(\mathrm{B}+\mathrm{R})$, wdrożenie i komercjalizację, czyli „klasyczny” proces innowacyjny, choć niekoniecznie liniowy;

4) dyskontowanie wartości $z$ innowacji: „Jak mamy odnieść $z$ tego korzyści?".

Autorzy później dodaja jeszcze ewentualnie fazę twórczego uczenia się, nawiązując do teorii pętli uczenia się, czyli odbierania sygnałów, które nie pozostają bez reakcji.

Ad 3. Komercjalizacja jako wprowadzenie innowacji na rynek rozpoczyna cykl życia produktu, stanowi zatem swojego rodzaju łącznik między procesem innowacyjnym a procesem życia nowego wyrobu na

\footnotetext{
${ }^{1} \mathrm{~W}$ polskim tłumaczeniu „wdrażanie”, co może mylić się z pracami wdrożeniowymi.
} 
rynku - zob. np. Garbarski, Rutkowski, Wrzosek [1996], Kotler [1994], Mruk i Rutkowski [1994].

Ad 4. Ostatnio na proces innowacyjny patrzy się jak na łańcuch tworzenia wartości - zob. np. Aho [2006], Christensen [2010] czy Janasz i Kozioł-Nadolna [2011]. Białoń [2010] traktuje komercjalizację jako dziewiąte ogniwo łańcucha wartości innowacji, składającego się łącznie $\mathrm{z}$ dwunastu ogniw.

Zauważmy, iż w podręczniku Oslo [OECD, 2005] wprowadzenie nowego produktu na rynek zalicza się (z wyjątkiem organizacji jego dystrybucji) do działalności innowacyjnej.

\section{Model procesowy innowacji}

Fazowe podejście do innowacji jest już jednak niewystarczające. Współcześnie proces innowacyjny to de facto zbiór różnych procesów o dużym stopniu skomplikowania i złożoności, co wynika m.in. z następujących powodów:

1) innowacja „stoi na dwóch nogach” [Jasiński, 2006]: podczas gdy ,jedna noga" tkwi jeszcze $w$ sferze $B+R$, druga tkwi już w sferze produkcji, a na przejściu między sferami odbywa się transfer (przepływ) nowej wiedzy naukowo-technicznej,

2) poszczególne procesy (cząstkowe) mogą odbywać się w różnych miejscach gospodarki narodowej, a nawet światowej, np. w ramach innowacji otwartej,

3) uczestnicy (podmioty) procesu innowacyjnego są bardzo zróżnicowani: firmy produkcyjne i inne, jednostki naukowe, różne instytucje, a także gospodarstwa domowe - np. w ramach tzw. innowacji prowadzonej przez użytkownika.

W związku z powyższym opracowany został kompleksowy model procesowy innowacji technicznej ${ }^{2}$. Na proces innowacyjny patrzymy tutaj:

1) przez pryzmat łańcucha wartości innowacji, każdy proces cząstkowy tworzy bowiem określoną wartość (cząstkową), oraz

2) z punktu widzenia przedsiębiorcy, co wynika stąd, że to właśnie firma (produkcyjna) jest zwykle miejscem, gdzie pojawia się innowacja, która następnie jest wprowadzana na rynek (innowacja produktowa) lub instalowana wewnątrz przedsiębiorstwa (innowacja procesowa).

\footnotetext{
${ }^{2}$ Został on opracowany przez Autora w projekcie badawczym: Analiza stosowanych w Polsce narzędzi wspomagania innowacyjności (grudzień 2012) w ramach Programu Strategicznego „Innowacyjne systemy wspomagania technicznego zrównoważonego rozwoju gospodarki”, koordynowanego przez Instytut Technologii Eksploatacji - PIB w Radomiu.
} 
Model ten tworzy zbiór procesów, przy czym w grę mogą wchodzić z punktu widzenia przedsiębiorstwa - następujące, nazwane umownie, procesy:

\section{Pomysły $\rightarrow$ B+R $\rightarrow$ Transfer $\rightarrow$ Wdrożenie $\rightarrow$ Komercjalizacja $\rightarrow$ Dyfuzja}

Zanim omówimy komercjalizację jako element tego modelu, należy wyjaśnić, że:

1) nie są to „klasyczne” fazy (etapy) procesu innowacyjnego, lecz raczej procesy składające się na współczesny mechanizm innowacji;

2) nie zawsze ma miejsce taka kolejność etapów; np. podczas badań naukowych może pojawić się, przypadkowo, pomysł na jakiś nowy produkt, który nie był brany wcześniej pod uwagę;

3) niektóre procesy, np. „Pomysły” oraz „B+R”, mogą odbywać się równolegle;

4) innowacja może, ale nie musi być oparta na wynalazku, który powstał podczas prac badawczo-rozwojowych;

5) w przypadku konkretnego procesu innowacyjnego nie muszą wystąpić wszystkie fazy, np.:

- jeśli nowe rozwiązanie naukowo-techniczne jest wynikiem prac badawczo-rozwojowych prowadzonych wewnątrz przedsiębiorstwa, transfer wiedzy nie będzie miał miejsca;

- jeśli firma kupiła licencję techniczna, co jest przejawem transferu, nie będzie wówczas generowania pomysłów i badań naukowych; co najwyżej mogą tu być potrzebne pewne uzupełniające prace rozwojowe;

- jeśli mamy do czynienia z innowacją procesową, nie wystapi proces

jej komercjalizacji, ponieważ nowa metoda produkcji zazwyczaj zostaje w firmie;

- nie musi, i czasami nie występuje, dyfuzja innowacji;

6) jedynym procesem, który musi mieć miejsce, jest wdrożenie, ponieważ to ono przesądza o tym, czy pojawi się innowacja, czy nie.

Zauważmy również, że tylko transfer nowej wiedzy naukowotechnicznej oraz dyfuzja innowacji technicznych nie są zaliczane do „klasycznego” (jak wyżej) procesu innowacyjnego. Dyfuzja stanowi jednak naturalne, pożądane uzupełnienie tego procesu. Notabene, są i tacy autorzy, jak np. Klincewicz [2011], którzy utożsamiają dyfuzję innowacji wśród nabywców z komercjalizacją. Wydaje się, iż nie jest to słuszne. Wreszcie, 
pomysły (inicjatywy) nowych produktów są często rezultatem badań rynkowych, a nie naukowych.

Autorzy pracy pod redakcją Matusiaka i Gulińskiego [2010] zbadali łącznie procesy transferu technologii i komercjalizacji wiedzy, wychodząc $\mathrm{z}$ założenia, że procesy te $\mathrm{w}$ praktyce towarzyszą sobie. Następnie przedstawili wizję nowoczesnego, spójnego i kompleksowego systemu transferu i komercjalizacji w polskiej gospodarce oraz sformułowali długa, szczegółową listę słusznych rekomendacji zmian w tym systemie.

Spójrzmy teraz na komercjalizację jak na wyodrębniony proces.

\section{Komercjalizacja jako proces}

W Polsce nowe rozwiązanie naukowo-techniczne powstaje zazwyczaj w jednym miejscu (np. w placówce badawczej), w innym miejscu jest ono wdrażane (np. w przedsiębiorstwie), a w jeszcze innym pojawia się jego zmaterializowana postać (tj. na rynku). Świadczy to o tym, jak ważną rolę ma do odegrania proces komercjalizacji, który powinien zacząć się odpowiednio wcześniej - zanim nowy wyrób zjawi się na rynku.

Proces komercjalizacji innowacji, który zwykle jest domeną przedsiębiorstwa wdrażającego, można umownie podzielić na następujące etapy [Jolly, 1997]:

1) uświadomienie wartości (wyjątkowości) i potencjału komercyjnego danego rozwiązania naukowo-technicznego, zebranie jak największej ilości informacji o nim, weryfikacja praw własności intelektualnej;

2) inkubacja, czyli określenie potencjału komercyjnego tego rozwiązania, przygotowanie planu komercjalizacji, analiza finansowa dla identyfikacji źródeł sfinansowania komercjalizacji oraz przygotowanie takiej wersji innowacji, która zostanie wprowadzona na rynek;

3) demonstracja, czyli prezentacja innowacji potencjalnym klientom i zebranie informacji zwrotnej na temat ich pierwszych reakcji ${ }^{3}$; faza ta jest czasami określana jako testowanie rynku;

4) promocja, rozumiana szeroko jako proces porozumiewania się z rynkiem; jest to działalność informacyjna, której celem jest popieranie (promotio) innowacji produktowej i jej producenta;

5) ekspansja i utrzymanie produktu na rynku, pełne wykorzystanie możliwości rozwoju tej innowacji.

Dwie pierwsze fazy mają charakter przygotowawczy, pozostałe wykonawczy. Kluczowy jest tutaj etap drugi, określany jako inkubacja innowacji. Jeśli chodzi o ustalenie jej potencjału komercyjnego, wielce

${ }^{3}$ Zauważmy, że w międzyczasie powinno nastąpić produkcyjne wdrożenie nowego rozwiązania naukowo-technicznego. 
pomocna może być metoda Quick-look (szybkie spojrzenie), opracowana w Instytucie IC2 na Uniwersytecie Teksańskim w Austin w USA. Zastosowanie tej metody obejmuje następujące elementy ${ }^{4}$ :

1) określenie potencjalnego(ych) rynku(ów) docelowego(ych) dla danej innowacji,

2) identyfikacja potencjalnych użytkowników innowacji i ewentualnych licencjobiorców,

3) uzyskanie opinii ekspertów i zainteresowanych przedsiębiorców na temat tej innowacji i możliwości jej wykorzystania,

4) identyfikacja szans i zagrożeń stanowiących bariery dla wdrożenia i komercjalizacji tej innowacji.

Raport z wykorzystania metody Quick-look powinien zawierać następujące części [Gwarda-Gruszczyńska, Czapla, 2001]:

1) opis innowacji,

2) korzyści wynikające z zastosowania innowacji,

3) potencjalne rynki,

4) zainteresowanie rynku,

5) stan rozwoju innowacji,

6) stan własności intelektualnej,

7) konkurencyjne technologie i konkurentów,

8) bariery wejścia na rynek,

9) rekomendacje.

Przeprowadzenie oceny tą metodą pozwala szybko uzyskać w miarę obiektywną i zestandaryzowaną informację o potencjale komercyjnym danej innowacji. Jeśli posiada ona taki potencjał, należy się nią dalej zajmować i przygotować plan komercjalizacji (do czego wrócimy poniżej).

Przed rozpoczęciem komercjalizacji należy rozstrzygnąć, czy innowację będziemy wprowadzać na rynek polski i/lub zagraniczny. Mamy do wyboru pięć wariantów - możemy wprowadzić nowy produkt [Jasiński, 1998]:

1) najpierw na rynek krajowy, a następnie na zagraniczny (wariant obecnie najbardziej rekomendowany dla polskich firm),

2) najpierw na rynek zagraniczny, a następnie na krajowy,

3) jednocześnie na rynek krajowy i zagraniczny,

4) tylko na rynek krajowy (w Polsce jest to najczęstszy przypadek),

5) tylko na rynek zagraniczny (bardzo rzadkie przypadki).

\footnotetext{
${ }^{4}$ Zob. www.ic2.utexas.edu. Zespół tego instytutu opracował również metodę In-Depth (tzw. wywiad głębinowy), która pozwala na pogłębioną, systematyczną analizę i ocenę potencjału komercyjnego innowacji.
} 
Obecnie, kiedy polska gospodarka jest częścią Jednolitego Rynku Unii Europejskiej, należy rozważać te warianty, które zakładają wprowadzanie nowości na rynki zagraniczne.

Potraktujmy proces komercjalizacji jako przedsięwzięcie, którym należy dobrze pokierować. Jest to bowiem przedsięwzięcie:

1) rozłożone (w czasie),

2) złożone (z wielu czynności, działań),

3) trudne w realizacji,

4) ryzykowne oraz

5) kosztowne,

co potwierdza, że potrzebny jest dobry plan komercjalizacji.

Proces ten można umownie podzielić na dwa etapy: etap wstępny, który odbywa się jeszcze zanim nowy produkt trafi na rynek, oraz etap właściwy, który rozpoczyna się z chwilą zaistnienia innowacji na rynku [Jasiński, 1998].

Etap wstępny obejmuje pięć podetapów:

1) przygotowanie wstępnego projektu planu sprzedaży na podstawie przeprowadzonych badań rynku oraz uzgodnień $\mathrm{z}$ jednostkami handlowymi i innymi odbiorcami,

2) testowanie rynku (dotyczy w zasadzie tylko dóbr konsumpcyjnych),

3) opracowanie i skoordynowanie trzech planów przedsiębiorstwa: planu zaopatrzenia, produkcji i zbytu,

4) rozpoczęcie promocji nowego produktu/technologii,

5) zgromadzenie odpowiedniej partii dostaw.

Etap wlaściwy zawiera cztery podetapy:

1) rozpoczęcie sprzedaży w normalnej skali poprzez uzgodnione kanały dystrybucji i po ustalonej cenie,

2) obserwacja i analiza rynku w miarę zwiększania sprzedaży,

3) utrzymywanie ścisłych kontaktów z pośrednikami handlowymi,

4) przeprowadzenie ewentualnych korekt dotyczących np. organizacji sprzedaży, ceny, instrumentów promocji czy opakowania (jeśli dotyczy).

Wszystkie te działania powinny być uwzględnione podczas przygotowywania planu komercjalizacji. Typowy plan komercjalizacji innowacji składa się z następujących elementów/planów cząstkowych [Gwarda-Gruszczyńska, Czapla, 2001]:

1) streszczenia kierowniczego,

2) charakterystyki przedsięwzięcia,

3) planu strategicznego,

4) planu marketingowego, 
5) planu finansowego,

6) planu organizacyjno-technicznego,

7) harmonogramu realizacji,

8) podsumowania i wniosków.

Kluczowym elementem jest tutaj plan strategiczny, oparty na jednej $\mathrm{z}$ dwóch stosowanych zwykle strategii wejścia $\mathbf{z}$ nowym wyrobem na rynek. Chodzi tu o strategię wypukłą lub wklęsłą [Sznajder, 1992] - zob. rysunek. Wybór właściwej strategii nie jest łatwy, zależy od wielu czynników. Dla polskich przedsiębiorstw, zwłaszcza małych i średnich, bardziej zalecana wydaje się strategia wklęsła, którą można określić jako „strategię drobnych kroczków”. Zakłada ona stopniowe, powolne wchodzenie z innowacją na rynek, a dopiero później - po opanowaniu rynku - przyspieszenie sprzedaży.

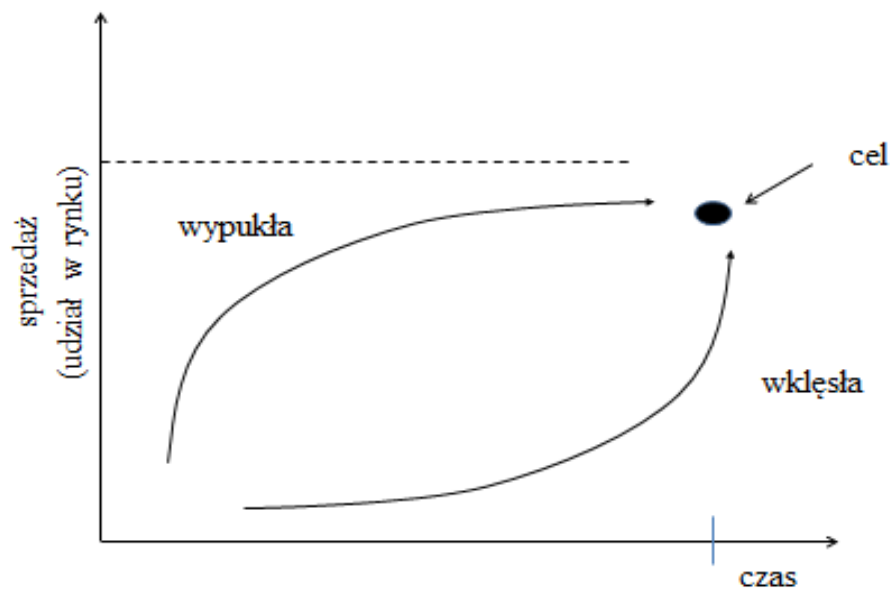

Rysunek 1. Strategie wejścia na rynek

Po dokonaniu wyboru jednego ze wspomnianych pięciu wariantów i jednej z dwóch strategii należy szczegółowo opracować strategię wejścia, odpowiadając na następujące pytania [Jasiński, 1998]:

1) „W jakim momencie nowy produkt powinien znaleźć się na rynku?”,

2) „Kiedy rozpocząć proces jego wprowadzania?”,

3) „Czy i jak przeprowadzić testowanie rynku?”,

4) „Jakiej docelowej grupie nabywców będzie on głównie oferowany?",

5) „W jakiej skali go sprzedawać?”, 
6) „W jakich kanałach dystrybucji?”,

7) „Jakie i w jakich proporcjach zastosować narzędzia promocji?”,

8) „Jaka będzie wysokość ceny i jak ma się ona potem kształtować (rosnąć czy maleć)?",

9) „Jakie nakłady finansowe przeznaczyć na proces wprowadzania?”,

10) „Jaki ma być zakres obsługi posprzedażnej?”,

11) „Jakie źródła i sposoby będą wykorzystane do zbierania informacji o reakcjach nabywców (użytkowników)?",

12) „Jakie działania podejmie się $w$ razie groźby niepowodzenia na rynku?",

13) „Jakie czynności zostaną podjęte w przypadku ewentualnych trudności z opanowaniem produkcji?".

Jak widać, głównym oparciem dla strategii komercjalizacji innowacji jest oparcie (wsparcie) marketingowe.

\section{Przesłanki marketingu nowego produktu}

Podstawowe przesłanki marketingu nowego produktu (innowacji produktowej) są następujące [Jasiński, 2012]:

1. Marketing potrzebny jest wszystkim uczestnikom procesu innowacyjnego, a zwłaszcza placówce naukowej i przedsiębiorstwu produkcyjnemu. Jednakże działania i badania marketingowe powinny obejmować przede wszystkim przyszłego użytkownika nowego produktu. Z punktu widzenia placówki naukowej tym użytkownikiem będzie przedsiębiorstwo, a $\mathrm{z}$ punktu widzenia firmy będzie nim konsument lub inny nabywca jej wyrobów (usług). Oczywiście zdecydowanie ważniejszy jest tutaj finalny użytkownik przyszłej innowacji.

Tak więc innowacja zakończy się sukcesem przede wszystkim wtedy, gdy potencjalny producent zadba o stały dialog, konsultacje z rynkiem. W trakcie takiego dialogu następować musi ciągła weryfikacja rezultatów kolejnych faz procesu innowacyjnego - począwszy od wiązki pomysłów na nowy produkt, a skończywszy na pierwszych reakcjach rynku na nowy wyrób znajdujący się już w normalnej sprzedaży $^{5}$.

2. Zdarza się, że przedsiębiorstwo ma już projekt techniczny lub wręcz gotowy, nowy produkt (np. sprowadzony $\mathrm{z}$ zagranicy) i dopiero wówczas zaczyna poszukiwać dlań nabywców na rynku. Tymczasem

5 Tak mniej więcej wygląda model tzw. user-driven innovation. Szerzej o metodach prowadzenia tego dialogu w pracy: A. H. Jasiński (1998): Innowacje techniczne a działalność marketingowa, Wydawnictwo WSPiZ, Warszawa, s. 89-92. 
marketing wymaga odwrotnej kolejności myślenia. Logikę marketingowego myślenia można streścić, parafrazując znane powiedzenie: „Pokaż mi Twoich klientów, a powiem $\mathrm{Ci}$, jak masz uprawiać marketing". Należy zatem zacząć od postawienia następujących pytań:

- „Czego będą potrzebować nasi klienci w przyszłości?”,

- „Kim są przyszli użytkownicy danej innowacji?”,

- „Czego oni oczekują od nowej techniki?”.

Tak więc najpierw trzeba badać i przewidywać popyt na innowacje, a dopiero później zaczynać prace nad nowymi rozwiązaniami naukowo-technicznymi - zarówno $\mathrm{w}$ przedsiębiorstwie, jak i w placówce naukowej. Inne są, rzecz jasna, metody badania popytu na nowe artykuły konsumpcyjne, a inne na dobra przemysłowe [Jasiński, 1998].

3. Współczesny marketing to marketing docelowy, tzn. adresowany do konkretnej grupy nabywców, a nie do jakiegoś typowego, przeciętnego nabywcy dominującego na danym rynku. Innymi słowy, działania marketingowe adresowane są do segmentu rynkowego, który tworzą nabywcy o bardzo podobnych potrzebach i zachowaniach. Zazwyczaj rynek danego produktu czy usługi składa się z kilku takich segmentów. Wywołuje to konieczność dokonania podziału, czyli segmentacji rynku. Dopiero wówczas można wybrać konkretny rynek (segment) docelowy lub też kilka odrębnych rynków docelowych.

Jednym $\mathrm{z}$ kryteriów segmentacji może być np. status klienta/użytkownika. Można wówczas wyodrębnić trzy grupy klientów i sformułować trzy pytania:

- klienci obecni - „Co zrobić, by ich utrzymać?”,

- byli klienci - „Co zrobić, by ich odzyskać?”,

- klienci potencjalni - „Co zrobić, by ich zdobyć?”.

Oczywiste jest, że również nowy produkt rynkowy musi mieć adresata, a zatem marketing innowacji także powinien mieć charakter docelowy. Oznacza to, że przed rozpoczęciem prac nad nowym produktem powinniśmy odpowiedzieć na następujące pytania:

- „Do kogo, czyli do którego rynku docelowego, przedsiębiorstwo będzie adresować swoje działania marketingowe?",

- „Jak duży (pojemny) jest ten rynek?”,

- „Jakie są jego cechy, tzn. czym charakteryzują się tworzący go nabywcy i ich zachowania rynkowe?".

4. Oferta produktowa jest często utożsamiana $\mathrm{z}$ ofertą rynkową. Jednakże oferta rynkowa firmy jest pojęciem znacznie szerszym. Produkt, 
traktowany w marketingu jako instrument oddziaływania na rynek, jest tylko jednym z jej elementów. Współcześnie oferta rynkowa rozumiana jest zwykle jako zbiór czterech użyteczności (korzyści) oferowanych nabywcy: formy, miejsca, czasu i posiadania. Tak też należy traktować innowację techniczną oferowaną potencjalnemu użytkownikowi. Może być ona przy tym treścią oferty:

- placówki naukowej, zwykle jako wiedza nie ucieleśniona; tutaj adresatem są przedsiębiorstwa oraz

- przedsiębiorstwa produkcyjnego, zazwyczaj jako wiedza ucieleśniona; tu adresatem może być inny producent lub konsument.

Taki zespół użyteczności można wykreować przy wykorzystaniu koncepcji mieszanki marketingowej (marketing mix), czyli 4P. Obejmuje ona, obok wspomnianych już elementów - produktu i promocji - również takie komponenty jak cena i dystrybucja. Nowy produkt musi mieć bowiem jeszcze odpowiednią cenę oraz zostać we właściwy sposób rozmieszczony (dystrybuowany) na rynku.

\section{Marketing mix innowacji produktowej}

Marketing na potrzeby działalności innowacyjnej należy rozumieć szerzej niż to się zwykle w literaturze przyjmuje, tzn. nie ograniczać się tylko do nowego produktu w sensie fizycznym i związanych z nim działań marketingowych producenta. Marketing traktujemy tutaj jako całościowe podejście, które obejmuje również działalność dotyczącą sprzedaży myśli naukowo-technicznej innym przedsiębiorstwom w kraju i za granica, a więc wyników prac badawczo-rozwojowych, licencji na nowy wyrób czy technologię wytwarzania oraz usług technicznych niezbędnych do opanowania nowej produkcji. Pojęcie marketingu innowacji wykracza zatem poza przedsiębiorstwo, ponieważ dotyczy również aktywności placówek naukowych. Tak rozumiany marketing powinien sprzyjać dyfuzji innowacji w gospodarce.

Sposób podejścia i zakres wykorzystania poszczególnych narzędzi mieszanki marketingowej przez przedsiębiorstwo zależy od wielu czynników, m.in. od stopnia zrównoważenia i konkurencyjności rynku. Zależy on jednak przede wszystkim od specyfiki rynku obsługiwanego przez danego producenta, a zwłaszcza od tego, czy jest to rynek przedmiotów konsumpcji, czy środków produkcji. Inne bowiem powinno być podejście innowatora do kształtowania cen, form obrotu (dystrybucji) i narzędzi promocji w przypadku nowych dóbr zaopatrzeniowo- 
inwestycyjnych, np. materiałów, surowców, obrabiarek, maszyn rolniczych czy budowlanych, a inne w przypadku nowych artykułów konsumpcyjnych.

Zastosowanie koncepcji mieszanki marketingowej obejmuje określoną sekwencję działań, stanowiącą niejako ciąg innowacji (zmian) w wyrobie, jego promocji, dystrybucji i cenie - zob. więcej: Jasiński [2011 lub 2012], a także Białoń [2012] oraz Kruk [2012].

\section{Konkluzje}

W odniesieniu do działalności badawczo-rozwojowej i innowacyjnej komercjalizację można rozpatrywać jako sprzedaż wyników prac $\mathrm{B}+\mathrm{R}$, jako ostatnią fazę procesu innowacyjnego (w węższym ujęciu), jako podetap jednego $\mathrm{z}$ etapów procesu innowacyjnego (w szerszym rozumieniu), jako jedno z ogniw łańcucha tworzenia wartości innowacji lub jako pierwszą fazę cyklu życia produktu na rynku.

Zalecane jest jednak traktowanie procesu komercjalizacji jako jednego z sześciu elementów modelu procesowego innowacji (technicznej). Takie procesowe podejście chyba najlepiej oddaje istniejącą rzeczywistość, w której poszczególne procesy mogą zazębiać się i coraz częściej odbywają się równolegle w różnych miejscach.

Bez umiejętnego marketingu komercjalizacja nie skończy się sukcesem. Działania marketingowe powinny uwzględniać specyfikę marketingu nowego produktu (innowacji produktowej).

\section{Referencje}

1. Aho E. (ed.), Creating an innovative Europe, European Commission, Brussels, 2006.

2. Białoń L., Zręby teorii innowacji, [w:] Białoń L. (red.): Zarzadzanie działalnościq innowacyjnq, Poltext, Warszawa, 2010.

3. Białoń L., Marketing $w$ działalności innowacyjnej - ogólne zasady, [w:] Jasiński A. H., Ciborowski R. (red.): Ekonomika i zarzqdzanie innowacjami, Wydawnictwo Uniwersytetu w Białymstoku, Białystok, 2012.

4. Christensen C., Przelomowe innowacje, PWN, Warszawa, 2010.

5. Garbarski L., Rutkowski I., Wrzosek W., Marketing, PWE, Warszawa, 1996.

6. Gwarda-Gruszczyńska E., Czapla T. P., Kluczowe kompetencje menedżera d/s komercjalizacji, Łódź (wersja elektroniczna), 2001.

7. Janasz W., Kozioł-Nadolna K., Innowacje $w$ organizacji, PWE, Warszawa, 2011. 
8. Jasiński A. H., Innowacje techniczne $i$ działalność marketingowa, WSPiZ, Warszawa, 1998.

9. Jasiński A. H., Innowacje i transfer techniki w procesie transformacji, Difin, Warszawa, 2006.

10. Jasiński A. H., Zarys marketingu innowacji, [w:] Jasiński A. H. (red.): Zarzqdzanie wynikami badań naukowych. Poradnik dla innowatorów, Wydawnictwo Naukowe Wydziału Zarządzania Uniwersytetu Warszawskiego i Instytutu Technologii Eksploatacji, WarszawaRadom, 2011.

11. Jasiński A. H., Założenia marketingu innowacji, [w:] Jasiński A. H., Ciborowski R. (red.): Ekonomika $i$ zarzadzanie innowacjami, Wydawnictwo Uniwersytetu w Białymstoku, Białystok, 2012.

12. Jolly V. K., Commercializing new technologies, Harvard Business Press, Boston, 1997.

13. Klincewicz K., Dyfuzja innowacji, Wydawnictwo Naukowe Wydziału Zarządzania Uniwersytetu Warszawskiego, Uniwersytet Warszawski, Warszawa, 2011.

14. Kotler Ph., Marketing, Gebethner, Warszawa, 1994.

15. Krawiec F., Zarzadzanie projektem innowacyjnym produktu $i$ ustugi, Difin, Warszawa, 2000.

16. Kruk M., Zarzqdzanie i marketing nowego produktu, [w:] Jasiński A. H., Ciborowski R. (red.): Ekonomika $i$ zarzadzanie innowacjami, Wydawnictwo Uniwersytetu w Białymstoku, Białystok, 2012.

17. Matusiak K. B., Guliński J. (red.), Rekomendacje zmian w polskim systemie transferu technologii i komercjalizacji wiedzy, PARP, 2010.

18. MNiSzW, Przewodnik: Komercjalizacja $B+R$ dla praktyków, Warszawa, 2010.

19. Mruk H., Rutkowski I. P., Strategia produktu, PWE, Warszawa, 1994.

20. OECD, The measurement of scientific and technological activities, Eurostat, Paris, 2005.

21. Pomykalski A., Zarzadzanie innowacjami, PWN, Warszawa-Łódź, 2001.

22. Rosseger G., The economics of production and innovation, Pergamon Press, Oxford, 1997.

23. Rutkowski I. P., Rozwój nowego produktu, PWE, Warszawa, 2007.

24. Sosnowska A. (red.),Zarzadzanie nowym produktem, Oficyna Wydawnicza SGH, Warszawa, 2000.

25. Sznajder A., Strategie marketingowe na rynku międzynarodowym, PWN, Warszawa, 1992. 
26. Tidd J., Bessant J., Zarzqdzanie innowacjami, Oficyna Wolters Kluwer, Warszawa, 2011.

\begin{abstract}
The theme of this article centers on the commercialization concept based on the model of technical innovations process. The discussion deals with three issues. The first is the problems of scientific research results commercialization. The second issue is the commercialization of new product. The last point focuses on effective marketing support to gain commercialization success.
\end{abstract}

